\title{
CALCULATION OF AIRCRAFT AREA ON SATELLITE IMAGES BY GENETIC ALGORITHM
}

\author{
A.R. Iskhakov, Bashkir State Pedagogical University named after M. Akmully, Ufa, \\ Russian Federation, intellab@mail.ru, \\ R.F. Malikov, Bashkir State Pedagogical University named after M. Akmully, Ufa, \\ Russian Federation, rfmalikov@mail.ru
}

\begin{abstract}
Classical genetic algorithm is used in a computational experiment, which is described in this article, to measure an area of the aircraft Boeing 737-300. Satellite images containing objects of interest are selected as initial data. The computational experiment consists of two steps. The first step presents the generalized formulas of values. These formulas are needed to select initial images, using the theory of modified descriptive algebra of images. After that, the initial data is formed according to the calculated values, i.e. the satellite image is chosen in the needed scale and the shooting angle. At the second step, a model of technical vision system (computer vision system) in the modified descriptive images algebra and a fitness function for the genetic algorithm are developed. Then varying parameters of the model are chosen and their optimization is carried out in MATLAB. The article demonstrates development of the model due to its complexity by additional imaging techniques. Experimentally it was found that the evolution of the model improves optimization results.

Keywords: measurement of an aircraft area; objective function; genetic algorithm; modified descriptive images algebra; combinatorial evaluation of a space; space of image states.
\end{abstract}

\section{Introduction}

Problems of remote identification of objects having technogenic origin, as well as detection and measuring of their characteristics and attributes, are still relevant $[1$, 2].The paper proposes an approach to the development and optimization of methods for processing and analyzing of images of the optical range, which are previous to the detection step. In this approach, description of the image processing and analysis is based on the mathematical apparatus of digital image processing and analysis, as well as the methodology of modified descriptive image algebra (MDIA) [3]. Optimization of the developed method is carried out by classical genetic algorithms (GA) [4]. A fitness function (which is an analog of a target function) represents an image analysis method, including the developed method of their processing. The initial data are presented by satellite images in the optical range or fragments of maps from the famous Internet map services (Google Maps, Yandex Maps, "Ufa"Airport (access: https://yandex.ru/maps//CVhW4KZR)) (Fig. 1).

\section{Evaluation of Computational Experiment Parameters}

Fig. 1 (right) shows an aircraft with dedicated expert boundaries, which completely define an area of the object of interest to recognize it.

The technique of computational experiment is described in [5, 6]. The aircraft image in Fig. 2 is characterized by a height of $n=99$ pixels, a width of $m=99$ 

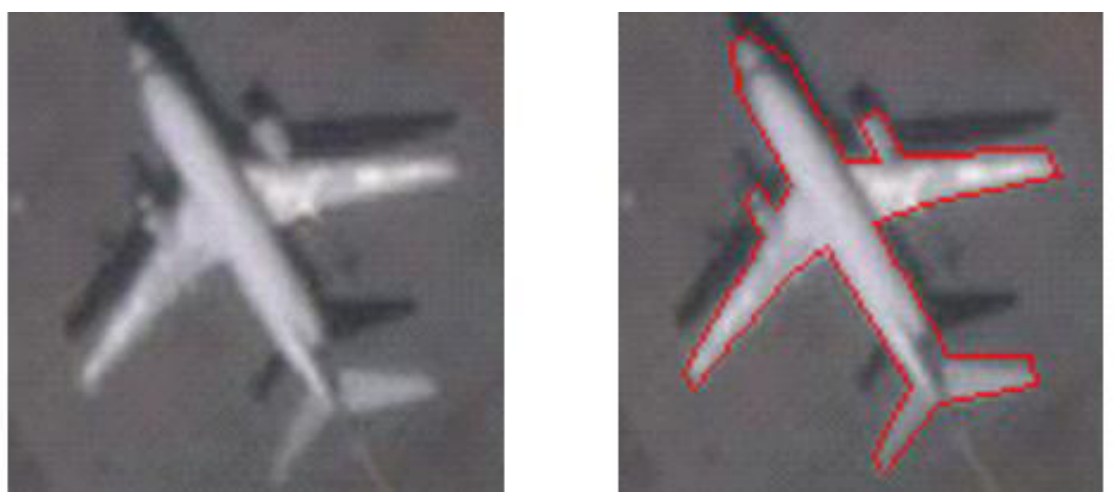

Fig. 1. Aircraft image (left) and its boundaries (right)

pixels and a resolution $d p c m=96$ pixel per inch of length (Boeing 737-300. (access: https://ru.wikipedia.org/wiki/Boeing_737)). Consequently, the height is $n=1,03125$ $\mathrm{cm}$, the width is $m=1,03125 \mathrm{~cm}$, the resolution is $d p \mathrm{~cm}=37,795$ pixel per $\mathrm{cm}$ of length $[3,5,6]$. Compute $[3,5,6]$ the number of pixels $\delta$ for accuracy $\varepsilon$ by the formula

$$
\delta=\left\lceil\frac{\varepsilon}{d p c m}\right\rceil
$$

The area of the passenger Boeing 737-300 aircraft for the top view is approximately $S \approx 328,702 \mathrm{~m}^{2}$. Let a measurement of the real area of an aircraft be produced with a precision $\varepsilon=50 \mathrm{~m}^{2}$, that is $15 \%$ from the total area $S$. At a desired altitude of satellite image shoot, 1 pixel covers $s_{e}=\frac{S}{p}=\frac{328,702}{2071} \approx 0,159 \mathrm{~m}^{2}$ of the area. Next, one can calculate the number of pixels in $15 \%$ of the error $\delta=\left\lceil\frac{2070 \cdot 15}{100}\right\rceil=\left\lceil\frac{31050}{100}\right\rceil=310,5 \approx$ 311 pixels, using a simple proportion between the values, see $[3,5,6]$. We define $p$ pixels $[3,5,6]$, which are significant in the planned reliable measurement by the formula

$$
S_{p i x}=p=\sum_{i=1}^{n} \sum_{j=1}^{m} z_{i j}, \quad I_{b i n}^{*}=\left\|z_{i j}\right\|, \quad z_{i j} \in S_{b i n} .
$$

Pixels of the aircraft (Fig. 1, right) area, which are bounded by a red border, are counted. The boundary is defined by an expert and $p=2070$ pixels. Only images having exactly $l=(1759 ; 2381)$ significant pixels are allowed for reliable measurement of the area. Then, substitute the values $\delta=311$ and $p=2070$ in (3) and calculate $[3,5,6]$ the coordinates of vector $\overrightarrow{k_{b i n}}$

$$
\overrightarrow{k_{b i n}}=\left(C_{n m}^{p-\delta}, \ldots, C_{n m}^{p+\delta}\right)=\left(C_{7254}^{1759}, \ldots, C_{7254}^{2381}\right) .
$$

Each of coordinates of this vector is the number of images $I_{b i n}^{*}=\left\|z_{i j}\right\|, \quad z_{i j} \in S_{b i n}$ in groups for $p$ significant pixels. According to $(4)$, the sum of vector $\overrightarrow{k_{b i n}}$ coordinates is an evaluation of a funnel section $K_{b i n}$ in MDIA [3, 5, 6]:

$$
K_{b i n}=\sum_{l=1759}^{2381} C_{7254}^{l}=0,3423393567 \cdot 10^{1993} .
$$


Let $\left\|z_{i j}\right\|=O_{T}^{g r a y \rightarrow b i n}\left(\left\|y_{i j}\right\|, \theta\right)$ be an operation to convert grayscale images $I_{\text {gray }}=\left\|y_{i j}\right\|, \quad y_{i j} \in S_{\text {gray }} \quad$ to binary images $\quad I_{b i n}=\left\|z_{i j}\right\|, \quad z_{i j} \in S_{b i n}$, where $z_{i j}=\left\{\begin{array}{ll}0, & \text { if } \quad y_{i j}<\theta \\ 1, & \text { if } \quad y_{i j} \geq \theta\end{array}\right.$ and $\theta$ is a conversion threshold [3]. The real value $\theta=64$ is matched by an expert according to the maximum inscribing of area of an object of interest in the previously defined border after converting to binary image. For $l=\overline{(p-\delta),(p+\delta)}$ significant pixels in the image $I_{b i n}^{*}=\left\|z_{i j}\right\|, \quad z_{i j} \in S_{b i n}$ for a conversion threshold $\theta=64$ of its inverse images it is $\theta^{n m-(p-\delta)} \cdot(256-\theta)^{(p-\delta)}, \ldots, \theta^{n m-(p+\delta)} \cdot(256-\theta)^{(p+\delta)}$ units respectively. Represent them $[3,5,6]$ as coordinates of the vector

$$
\overrightarrow{\theta_{\text {gray }}}=\left(\theta_{p-\delta}^{\text {gray }}, \ldots, \theta_{p+\delta}^{\text {gray }}\right)=\left(\theta^{n m-(p-\delta)} \cdot(256-\theta)^{(p-\delta)}, \ldots, \theta^{n m-(p+\delta)} \cdot(256-\theta)^{(p+\delta)}\right) .
$$

Substitute the values $n=99, m=99, \delta=311, p=2070$ and $\theta=64$ (as determined by the expert) into (5) and calculate the coordinates of vector $\overrightarrow{\theta_{\text {gray }}}$ for the considered problem:

$$
\overrightarrow{\theta_{\text {gray }}}=\left(64^{1759} \cdot 192^{5495}, \ldots, 64^{2381} \cdot 192^{4873}\right) \text {. }
$$

Thus, the size of a funnel section $K_{\text {gray }}$ is calculated $[3,5,6]$ as a scalar product of vectors $\overrightarrow{k_{\text {bin }}}$ and $\overrightarrow{\theta_{\text {gray }}}$ according to

$$
K_{\text {gray }}=\overrightarrow{k_{\text {bin }}} \cdot \overrightarrow{\theta_{\text {gray }}}=\sum_{l=p-\delta}^{p+\delta} k_{l}^{\text {bin }} \cdot \theta_{l}^{\text {gray }}=\sum_{l=p-\delta}^{p+\delta} C_{n m}^{l} \cdot \theta^{n m-l} \cdot(256-\theta)^{l} .
$$

For the considered problem there is a value

$$
K_{\text {gray }}=\sum_{l=1759}^{2381} k_{l}^{\text {bin }} \cdot \theta_{l}^{\text {gray }}=\sum_{l=1759}^{2381} C_{7254}^{l} \cdot 64^{l} \cdot 192^{7254-l}=0,2190920805 \cdot 10^{17470}
$$

Since color images are represented in RGB-space [3], then the color layers are independent from each other. Therefore, the evaluation of the size of funnel section

$$
K_{\text {color }}=\left(K_{\text {gray }}\right)^{3}
$$

for color MDIA $\mathrm{A}_{\text {color }}=\left\langle M_{\text {color }}, F_{\text {color }}\right\rangle$ is correct $[3,5,6]$. For the considered problem we obtain an evaluation

$$
K_{\text {color }}=\left(\sum_{l=1759}^{2381} C_{7254}^{l} \cdot 64^{l} \cdot 192^{7254-l}\right)^{3}=0,1051671340 \cdot 10^{52409} .
$$

According to $(7)$, one can calculate $[3,5,6]$ the probability that given images are in a funnel section in MDIA of color images

$$
P^{*}=P\left(I_{\text {color }} \in N_{\text {color }}\right)=\frac{K_{\text {color }}}{256^{3 n m}}=\frac{0,105167134 \cdot 10^{52409}}{0,131257799 \cdot 10^{52409}} \approx 0,8 .
$$




\section{Search for the Optimal Values of the Filter Mask and Conversion Threshold}

Mathematical method of modelling of image processing and analysis to calculate the aircraft area is represented in MDIA as follows:

$$
\begin{aligned}
& S_{\text {pix }}=\operatorname{Alg}\left(I_{\text {color }} ;<n, \theta>\right) \\
& \left\{I_{\text {bin }}=\left\|z_{i j}\right\|, \quad I_{\text {gray }}=\left\|y_{i j}\right\|, I_{\text {color }}=\left\|<r_{i j}, g_{i j}, b_{i j}>\right\|\right. \\
& \left\|y_{i j}\right\|=O_{T}^{\text {color } \rightarrow \text { gray }}\left(\left\|x_{i j}\right\| ; *\right), \quad y_{i j}=\left\lceil\frac{r_{i j}+g_{i j}+b_{i j}}{3}\right\rceil \\
& \left\|\overline{y_{i j}}\right\|=O_{T}^{\text {medfilter }}\left(\left\|y_{i j}\right\| ;(n, n)\right), \\
& \overline{y_{i j}}=\operatorname{med}\left\{f_{k=\overline{1, n \bullet n}} \mid\left(f_{k} \leq f_{k+1}\right) \wedge\left(f_{k} \in\left\{y_{i-n, j-n}, \ldots, y_{i+n, j+n}\right\}\right)\right\} \\
& \left\|z_{i j}\right\|=O_{T}^{\text {gray } \rightarrow \text { bin }}\left(\left\|255-\overline{y_{i j}}\right\| ; *\right), \quad z_{i j}=\left\{\begin{array}{cc}
0, & 255-\overline{y_{i j}}<\theta \\
1, & 255-\overline{y_{i j}} \geq \theta
\end{array}\right. \\
& \left.S_{\text {pix }}=\sum_{i} \sum_{j} z_{i j}\right\} .
\end{aligned}
$$

\begin{tabular}{|c|c|}
\hline Function of area measurement & Comments to program \\
\hline 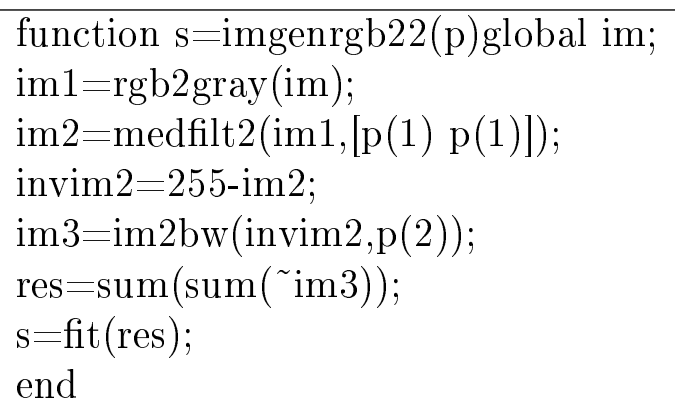 & $\begin{array}{l}\text { converting of a color image } \\
\text { use of a median filter } \\
\text { halftone image inversion } \\
\text { converting to binary image } \\
\text { calculation of sum of black dots } \\
\text { calculation of GA fitness function }\end{array}$ \\
\hline
\end{tabular}

Two parameters - the aperture of median filter $(n, n)$, and the conversion threshold $\theta$ of grayscale images into binary ones - are varied during image processing (converting) in (9). The table below shows the program written in MATLAB language, corresponding to method (9).

Table

MATLAB program with methods of filtration and conversion

Fig. 2 shows the surface described by method (9) and the function of area measurement for $n \in[2 ; 10]$ and $\theta \in[0 ; 1]$.

On the basis of Fig. 2 it can be concluded that a function of area measurement (table) reaches a minimum value 0 at more than one point. For example, a pair $\langle n, \theta\rangle=\langle 5,0,6\rangle$ is such point of extreme. However, an imposition of the processed image (Fig. 3, left) and the original one (Fig. 3, right) shows that a deviation in the desired pixels exists even with a minimum value of GA fitness function (objective function).

In plain language, this problem can be formulated as follows. The method of image processing and analysis (9) retains shape of the object of interest with all its features. Some significant pixels of the object are lost during conversion. Lost pixels are replaced with new "pseudo pixels" of the object of interest. It can be explained by use of the operation 


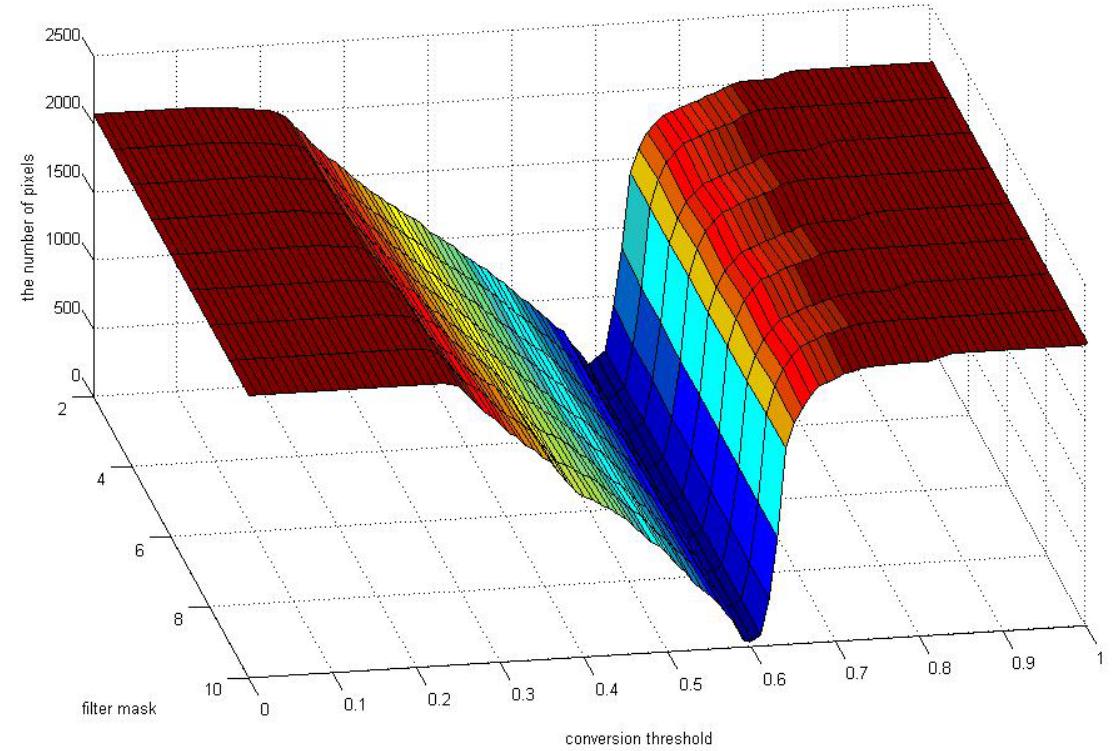

Fig. 2. The graph of GA fitness function for method (9)
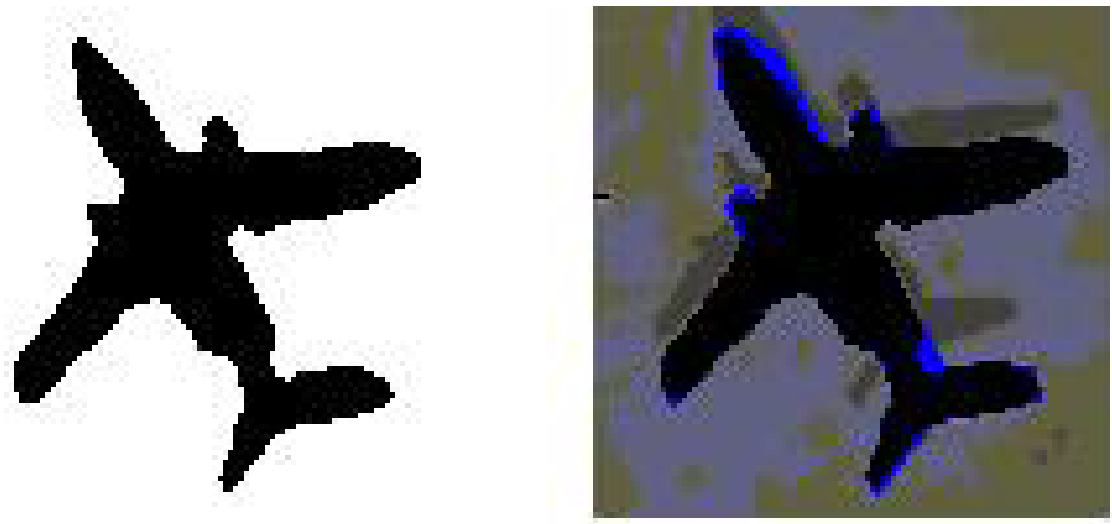

Fig. 3. Measurement of aircraft area for a filter mask $n=5$ and conversion threshold $\theta=0,6$ (left), and an imposition of the image area (left) to the real aircraft image (right)

of averaging of the adjacent pixels brightness by median filter (Fig. 3, right). Due to this fact the analysis (aircraft area measurement) remains within acceptable accuracy. The increasing of the complexity of image processing and analysis method (9) by methods of image restoration and morphological analysis allows to minimize the number of "false" pixels in the object of interest and refine a model of the object of interest (Fig. 3, left).

\section{Conclusion}

The use of genetic algorithms in the modified descriptive image algebra allows to simplify the computational process of image analysis. The paper describes an example about calculation of the Boeing 737-300 aircraft area for the top view by this method. The main result of this research paper is the rejection of image models in the classic view. 


\title{
References
}

1. Bartalev S.A., Galeev A.A., Efremov V.Y., Zlatopolsky A.A., Lupyan E.A., Mazurov A.A., Proshin A.A., Flitman E.V., Scherbenko E.V. [More Precise Automatic Burnt Out Forest Places Space Detection Using HRV, HRVIR Data]. Sovremennye problemy distantsionnogo zondirovaniya Zemli iz kosmosa [Current problems in remote sensing of the Earth from space], 2009, no. 6, pp. 335-342. (in Russian)

2. Potapov A.A., Gulyaev Yu.V., Nikitov S.A., Pakhomov A.A., German V.A. Noveyshie metody obrabotki izobrazheniy [The Latest Image Processing Techniques]. Moscow, FIZMATLIT, 2008. $496 \mathrm{p}$.

3. Iskhakov A.R., Malikov R.F. Modelling of Technical Vision Systems in the Modified Descriptive Image Algebra. Ufa, Publisher BSPU, 2015. (in Russian)

4. Burakov M.V. Genetic Algorithm: Theory and Practice. St. Petersburg, SUAE, 2008. (in Russian)

5. Iskhakov A.R. [Parametric Synthesis of Technical Vision Systems in the Modified Descriptive Image Algebras]. Research Science City, 2015, vol. 12, no. 2, pp. 24-31. (in Russian)

6. Iskhakov A.R. Mathematical Methods of Modeling of Image Processing and Analysis in the Modified Descriptive Algebras of Images. Journal of Computational and Engineering Mathematics, 2016, vol. 3, no. 1, pp. 3-9.

Received June 7, 2016

УДК 51-74

DOI: $10.14529 / \mathrm{mmp} 160414$

\section{ВЫЧИСЛЕНИЕ ПЛОЩАДИ САМОЛЕТА НА СПУТНИКОВЫХ СНИМКАХ ГЕНЕТИЧЕСКИМ АЛГОРИТМОМ}

\author{
А.Р. Исхаков, Р.Ф. Маликов
}

В статье описан вычислительный эксперимент, в котором для измерения площади самолета Boeing 737-300 используется классический генетический алгоритм. В роли начальных данных выбраны спутниковые снимки, содержащие объекты интереса. Вычислительный эксперимент состоит из двух этапов. На первом этапе приводятся обобщенные формулы величин, необходимые для выбора начальных изображений, с использованием теории модифицированных дескриптивных алгебр изображений. Далее с учетом вычисленных значений величин происходит формирование начальных данных, т.е. выбор спутникового снимка в нужном масштабе и угле съемки. На второй стадии разрабатывается модель системы технического зрения (системы компьютерного зрения) в модифицированных дескриптивньх алгебрах изображений и функция пригодности для генетического алгоритма. Далее выбираются варьируемые параметры модели и проводится их оптимизация в среде MATLAB. В статье демонстрируется развитие модели за счет ее усложнения дополнительными методами обработки изображений. Экспериментально было установлено, что эволюция модели улучшает результаты оптимизации.

Ключевые слова: измерение площади самолета; целевая функиия; генетический алгоритм; модифицированная дескриптивная алгебра изображений; комбинаторная оценка пространства; пространство состояний изображения. 


\section{Литература}

1. Автоматизированное уточнение площадей, пройденных лесными пожарами, по данным приборов HRV, HRVIR / С.А. Барталев, А.А. Златопольский, А.А. Галеев, В.Ю. Ефремов, Е.А. Лупян, А.А. Мазуров, А.А. Прошин, Е.В. Флитман, Е.В. Щербенко // Современные проблемы дистанционного зондирования Земли из космоса. - 2009. - № 6. C. $335-342$.

2. Новейшие методы обработки изображений / А.А. Потапов, Ю.В. Гуляев, С.А. Никитов, А.А. Пахомов, В.А. Герман. - М.: ФИЗМАТЛИТ, 2008. - 496 с.

3. Исхаков, А.Р. Моделирование систем технического зрения в модифицированных дескриптивных алгебрах изображений / А.Р. Исхаков, Р.Ф. Маликов. - Уфа: Изд-во БГПУ, 2015 .

4. Бураков, М.В. Генетический алгоритм: теория и практика / М.В. Бураков. - СПб.: ГУАП, 2008.

5. Исхаков, А.Р. Параметрический синтез систем технического зрения в модифицированных дескриптивных алгебрах изображений / А.Р. Исхаков // Исследования наукограда. - 2015. - Т. 12, № 2. - С. 24-31.

6. Iskhakov, A.R. Mathematical Methods of Modeling of Image Processing and Analysis in the Modified Descriptive Algebras of Images / A.R. Iskhakov // Journal of Computational and Engineering Mathematics. - 2016. - V. 3, №1. - P. 3-9.

Алмаз Раилевич Исхаков, преподаватель, кафедра «Информационные и полиграфические системы и технологии», Башкирский государственный педагогический университет им. М. Акмуллы (г. Уфа, Российская Федерация), intellab@mail.ru.

Рамиль Фарукович Маликов, доктор физико-математических наук, профессор, кафедра «Информационные и полиграфические системы и технологии», Башкирский государственный педагогический университет им. М. Акмуллы (г. Уфа, Российская Федерация),rfmalikov@mail.ru.

Поступила в редакцию 7 июня 2016 г. 